\title{
花生壳制备微孔炭及其在电化学超级电容器中的应用
}

\author{
郭培志 ${ }^{1, *} \quad$ 季倩倩 $^{1} \quad$ 张丽莉 $^{2} \quad$ 赵善玉 $^{2}$ 赵修松 ${ }^{1,2, *}$
}

('青岛大学化学化工与环境学院, 纤维新材料与现代纺织国家重点实验室培育基地, 山东青岛 266071; ${ }^{2}$ Department of Chemical and Biomolecular Engineering, National University of Singapore, 4 Engineering Drive 4, Singapore 117576)

摘要: 以未使用和使用氢氧化钠溶液处理的花生壳为碳源分别制备出微孔炭PSC-1 和 PSC-2. PSC-1 和 PSC-2 的比表面积分别为 552 和 $726 \mathrm{~m}^{2} \cdot \mathrm{g}^{-1}$, 其主要孔径都约为 $0.8 \mathrm{~nm}$. 用 PSC-1 和 PSC-2 制备的电极和对 称型超级电容器的循环伏安曲线均接近矩形, 表明其具有良好的电容特性. 在以微孔炭电极为工作电极、铂电 极为对电极和银 $/$ 氯化银电极为参比电极组成的三电极体系测量表明, 在 $0.1 \mathrm{~A} \cdot \mathrm{g}^{-1}$ 的电流密度下, PSC-1 和 PSC-2 的比电容达到 233 和 $378 \mathrm{~F} \cdot \mathrm{g}^{-1}$. 经过 1000 次恒电流充放电循环后, 在三电极体系和超级电容器中电极 均表现出良好的稳定性和电容保持率. 基于实验结果探讨了微孔炭的形成机理及其结构与电化学性质之间的 联系.

关键词: 超级电容器; 电极; 微孔炭; 花生壳; 电容 中图分类号: 0646

\section{Preparation and Characterization of Peanut Shell-Based Microporous Carbons as Electrode Materials for Supercapacitors}

\author{
GUO Pei-Zhi ${ }^{1, *} \quad$ JI Qian-Qian ${ }^{1} \quad$ ZHANG Li-Li ${ }^{2} \quad$ ZHAO Shan-Yu² $\quad$ ZHAO Xiu-Song ${ }^{1,2, *}$ \\ ('Laboratory of New Fiber Materials and Modern Textile, the Growing Base for State Key Laboratory, School of Chemistry, \\ Chemical Engineering and Environmental Sciences, Qingdao University, Qingdao 266071, Shandong Province, \\ P. R. China; ${ }^{2}$ Department of Chemical and Biomolecular Engineering, National University of Singapore, \\ 4 Engineering Drive 4, Singapore 117576)
}

\begin{abstract}
Microporous carbons (PSC-1 and PSC-2) were obtained directly by the carbonization of peanut shells without and with $\mathrm{NaOH}$ solution pretreatment, respectively. Both samples have a main pore size of $\sim 0.8 \mathrm{~nm}$. The surface area increases from $552 \mathrm{~m}^{2} \cdot \mathrm{g}^{-1}$ for PSC-1 to $726 \mathrm{~m}^{2} \cdot \mathrm{g}^{-1}$ for PSC-2. Cyclic voltammograms (CVs) of the PSC-1 and PSC-2 electrodes and the symmetrical supercapacitors show almost rectangular shape indicating excellent capacitance features. The specific capacitances of PSC-1 and PSC-2 can reach 233 and $378 \mathrm{~F} \cdot \mathrm{g}^{-1}$, respectively, at a current density of $0.1 \mathrm{~A} \cdot \mathrm{g}^{-1}$ in a three-electrode system using porous carbon as the working electrode, a platinum electrode as the counter electrode and a $\mathrm{Ag} / \mathrm{AgCl}$ electrode as the reference electrode. Furthermore, the electrodes in both three-electrode systems and supercapacitors show high stability and capacitance retainability after 1000 cycles. The formation mechanisms for the two microporous carbons and the relationship between the carbon materials and their electrochemical properties are discussed based on the experimental results.
\end{abstract}

Key Words: Supercapacitor; Electrode; Microporous carbon; Peanut shell; Capacitance

\footnotetext{
Received: July 18, 2011; Revised: September 26, 2011; Published on Web: October 13, 2011.

"Corresponding authors. GUO Pei-Zhi, Email: pzguo@qdu.edu.cn; Tel: +86-532-83780378. ZHAO Xiu-Song, Email:chezxs@qdu.edu.cn. The project was supported by the National Natural Science Foundation of China (20803037, 21143006), Foundation of Qingdao Municipal Science and Technology Commission, China (11-2-4-2-(8)-jch) and “Taishan Scholar” Program of Shandong Province, China. 国家自然科学基金(20803037, 21143006), 青岛市应用基础研究项目(11-2-4-2-(8)-jch)和“泰山学者”计划资助

(C) Editorial office of Acta Physico-Chimica Sinica
} 


\section{Introduction}

Electrochemical double-layer capacitors (EDLCs) are promising power sources because the demand for energy storage devices is increasing as a result of the fast-growing market for portable electronic devices and hybrid electric vehicles. ${ }^{1-3}$ The capacitance of EDLCs comes from charge accumulation at the electrode/electrolyte interface, and is therefore strongly dependent on the pore size and the surface area of the electrode accessible to the electrolyte. ${ }^{4-6}$ Among the various electrode materials for EDLCs, porous carbons are the most popular because of their high surface area, low cost, good electrical conductivity, and excellent chemical stability. ${ }^{6-9}$

There are several approaches to prepare porous carbon. One is the direct high-temperature carbonization of appropriate precursors. ${ }^{10,11}$ The other uses a template to prepare composites of the template and carbon precursor, and the mixed composites are then carbonized. ${ }^{6,7}$ Many researchers also use alkali/salt activation methods consisting of treating a mixture of the precursors and an alkali/salt at high temperature. ${ }^{12,13}$ For example, Béguin et $a l .^{10}$ reported that porous carbon derived directly by carbonization of sodium alginate had a capacitance as high as $200 \mathrm{~F} \cdot \mathrm{g}^{-1}$. Zhang et $a l .{ }^{12}$ reported that oxygen-rich activated carbons prepared from bituminous coal by a high-temperature activation method had a specific capacitance of $370 \mathrm{~F} \cdot \mathrm{g}^{-1}$. Recently, we have shown that the carbonization temperature has a significant effect on the electrochemical properties of chitosanbased porous carbons. ${ }^{11}$

Peanuts are widely planted in China, and the total amount can reach 14 million tons per year. Some of the peanut shells are used as animal feed and for cultivation of edible fungi, but a large proportion of the shells are unused. It is necessary to explore possible applications of peanut shells as well as other waste biomass. ${ }^{14-21}$ Recently, peanut shells have been used to fabricate porous carbons, which show many potential applications, ${ }^{14-16}$ for example as sorbents for metal ions ${ }^{14}$ and as Li-ion battery electrode materials. ${ }^{16}$ The activation method is usually use to fabricated activated carbons from peanut shell based on the solid mixture of the precursors and $\mathrm{KOH}$ or $\mathrm{ZnCl}_{2},{ }^{10-13}$ however, peanut shells are pretreated using aqueous $\mathrm{NaOH}$ solution before carbonization in our work. It is found that the pretreatment process has a strong effect on the physical and electrochemical properties of the peanut-shell-based microporous carbons. The electrochemical properties of the samples are characterized by cyclic voltammetry $(\mathrm{CV})$, galvanic charge-discharge, and cycling experiments.

\section{Experimental}

\subsection{Materials}

Peanut shells were obtained from peanuts purchased at Qingdao market. $\mathrm{NaOH}$ and $\mathrm{KOH}$ (AR grade) were purchased from the Sinopharm Chemical Reagent Company. Acetylene carbon black $(99.99 \%)$ and polytetrafluoroethylene (PTFE, with mass fraction of $60 \%$ ) latex were purchased from Strem Chemicals and Aldrich, respectively. All chemicals were used without further purification.

\subsection{Preparation of porous carbons}

The peanut shells were rinsed with water, dried, and then cut into small pieces (PS-1). Some peanut shells had been pretreated in an aqueous $\mathrm{NaOH}$ solution $\left(1 \mathrm{~mol} \cdot \mathrm{L}^{-1}\right)$ at $80{ }^{\circ} \mathrm{C}$ for $12 \mathrm{~h}$, and then the treated peanut shells were washed with water, dried and cut into pieces (PS-2). Porous carbons were obtained by carbonization of the peanut shells in a tube furnace at $800{ }^{\circ} \mathrm{C}$ for 90 min under a nitrogen flow. The heating rate was $10^{\circ} \mathrm{C}$. $\min ^{-1}$. The obtained black solid was then immersed into HF (20\%, mass fraction) solutions for $48 \mathrm{~h}$. Finally, the solid was filtered with water and dried at $60{ }^{\circ} \mathrm{C}$ for $6 \mathrm{~h}$. The samples referred to as PSC-1 and PSC- 2 were derived from PS- 1 and PS-2, respectively.

\subsection{Characterization of porous carbons}

The pore structures of the samples were investigated by physical adsorption of nitrogen at liquid nitrogen temperature $(77 \mathrm{~K})$ on an automatic volumetric sorption analyzer (NOVA 1100, Quantachrome). The specific surface area was determined by the Brunauer-Emmett-Teller (BET) method. Pore size distribution was evaluated by the Barrett-Joyner-Halenda (BJH) method. Elemental analyses were performed on a VARIO EL III elemental analyses system (Elementar Analysensysteme $\mathrm{GmbH}$, Hanau, Germany). Fourier transform infrared (FTIR) spectra were recorded on a Thermo Nicolet 5700 spectrophotometer. X-ray powder diffraction (XRD) measurements were determined using a Bruker D8 advanced X-ray diffractmeter equipped with $\mathrm{Cu} K_{\alpha}$ radiation $(\lambda=0.15418 \mathrm{~nm})$.

\subsection{Fabrication of porous carbon electrodes}

The electrochemical measurements were performed on an Autolab PGSTAT302N in an aqueous $\mathrm{KOH}$ solution (6 mol • $\left.\mathrm{L}^{-1}\right)$ at room temperature using a three-electrode cell with porous carbon as the working electrode, a platinum electrode as the counter electrode, and an $\mathrm{Ag} / \mathrm{AgCl}$ electrode as the reference electrode. The porous carbon electrodes were obtained by pressing a well-mixed slurry (80\% (mass fraction) carbon, $15 \%$ acetylene carbon black, and 5\% PTFE) onto a nickel foam grid $(1 \mathrm{~cm} \times 1 \mathrm{~cm})$ at $1.25 \times 10^{7} \mathrm{~Pa}$. The typical mass load of each electrode material was about $5 \mathrm{mg}$. The electrodes were vacuum dried at $110{ }^{\circ} \mathrm{C}$. Symmetrical sandwich-type supercapacitors made of two carbon pallets separated by fibrous paper and the electrode materials composed of $80 \%$ carbon (10 $\mathrm{mg}), 10 \%$ acetylene carbon black, and 10\% PTFE.

\section{Results and discussion}

Nitrogen sorption isotherms were recorded to determine the pore properties of the peanut-shell-based porous carbons (Fig.1). It can be seen that the data for PSC-1 and PSC-2 are almost the same, except that the surface area of PSC-2 is larger than that of PSC-1. At low pressure, the initial step region ascends abruptly and then follows a plateau (Fig.1A), indicating that adsorption has virtually stopped because of the pore wall 

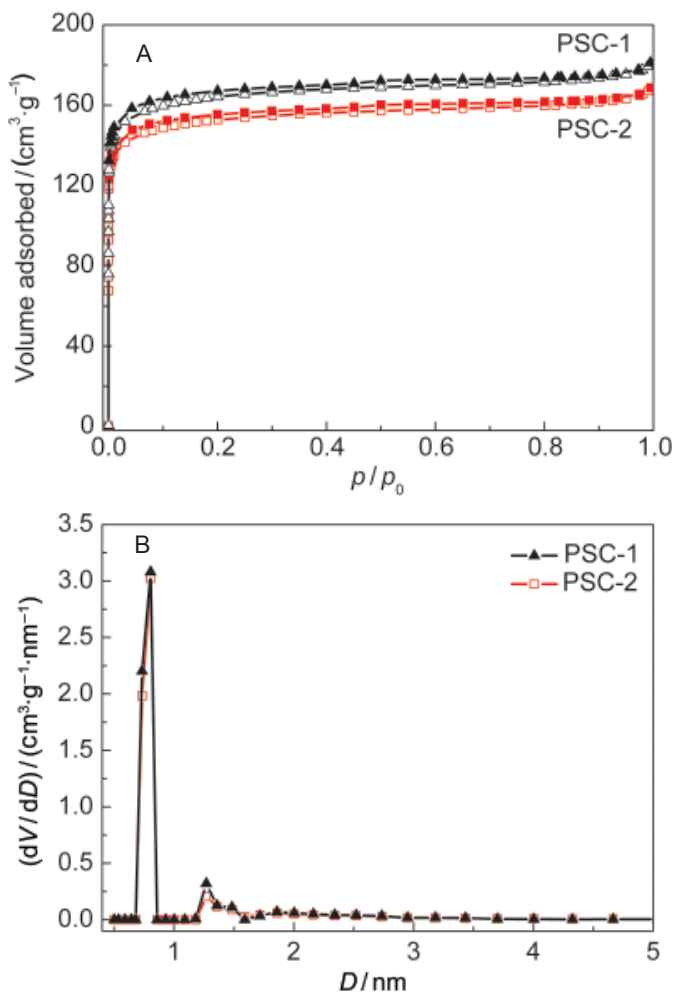

Fig.1 Nitrogen adsorption-desorption isotherms (A) and pore size distribution (B) of PSC-1 and PSC-2

multilayer. Both isotherms are type IV isotherm curves. It can be seen from Fig.1B that for both porous carbons the major pore size of particles is $\sim 0.8 \mathrm{~nm}$, with a minor part of $\sim 1.3 \mathrm{~nm}$. However, the surface area increases from $552 \mathrm{~m}^{2} \cdot \mathrm{g}^{-1}$ for PSC-1 to $726 \mathrm{~m}^{2} \cdot \mathrm{g}^{-1}$ for PSC-2. These changes are ascribed to the pretreatment with $\mathrm{NaOH}$ solution, which may enable some pectin and hemicelluloses (lignin, and wax like substances) to separate from the peanut shell and contribute to the increase in the specific surface area and pore volume. ${ }^{22}$ This will be further confirmed by the FTIR results. The pore sizes of PSC- 1 and PSC-2 are suitable for EDLC; ${ }^{1,23}$ they allow ion migration of inorganic electrolytes and electronic adsorption because the diameters of $\mathrm{K}^{+}$and $\mathrm{OH}^{-}$in the $\mathrm{KOH}$ solution are smaller than $0.4 \mathrm{~nm}^{24}$

FTIR spectroscopy can give direct structural information in the peanut shells during various chemical treatments. It can be seen from the FTIR spectra of PS-1 and PS-2 (Fig.2) that most of the absorption peaks are not shifted. For example, the absorption peaks at $3420 \mathrm{~cm}^{-1}$, ascribed to the $\mathrm{OH}$ group, and the peaks in the fingerprint regions at 1424, 1158, and $1054 \mathrm{~cm}^{-1}$, attributed to the cellulose structure, are virtually unchanged in both peanut shell samples. ${ }^{22}$ The absorption band at $1635 \mathrm{~cm}^{-1}$, ascribed to asymmetric $\mathrm{COO}$ - stretching, and the bands at 1458 and $1378 \mathrm{~cm}^{-1}$, assigned to the $\mathrm{CH}_{2}$ and $\mathrm{CH}$ symmetric bending modes, are also unchanged. However, the vibrational peak at $1738 \mathrm{~cm}^{-1}$ in the PS-1 spectrum, which is ascribed to $\mathrm{C}=\mathrm{O}$ stretching of the methyl ester and carboxylic acid groups in pectin, or the acetyl group in the hemicelluloses, disap-

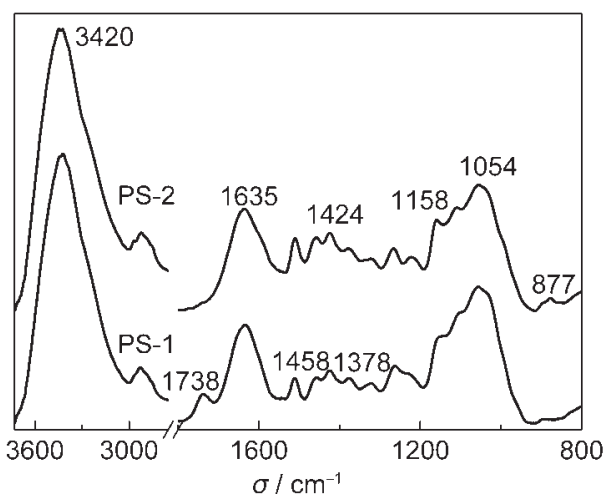

Fig.2 FTIR spectra of PS-1 and PS-2

peared from the PS-2 spectrum. This indicates that pectin and hemicelluloses can be successfully extracted by a simple alkaline solution treatment. ${ }^{22}$ A new band at $877 \mathrm{~cm}^{-1}$ in the PS-2 spectrum, ascribed to an epoxy compound, gives further information on the efficiency of the pretreatment. Furthermore, the mass contents $(\%)$ of $\mathrm{C}, \mathrm{N}, \mathrm{S}$, and $\mathrm{H}$, based on the elemental analyses data, are 92.13, 0.79, 0.36, and 1.01 for PSC-1, and 92.30, 0.48, 0.36, and 0.81 for PSC-2.

Fig. 3 shows the CV curves of PSC- 1 and PSC-2 based electrodes in three-electrode systems or symmetrical supercapacitors at different scan rates. Fig.3(A, C) displays that the $\mathrm{CV}$ curves of the electrodes in three-electrode systems have an almost rectangular shape, even at high scan rates, indicating that electrodes based on PSC-1 and PSC-2 have good capacitance $^{4-7}$ and fast charge-discharge switching. ${ }^{25}$ PSC-1 and PSC-2 electrodes all have large specific currents. Furthermore, the specific currents for the PSC-2 electrode are larger than those of the PSC-1 electrode, indicating that the PSC-2 electrode has a lower resistance and higher capacitance than that of the PSC-1 electrode. ${ }^{3}$ For symmetrical supercapacitors (Fig.3 (B, D)), all the CVs of the composites at a scan rate of $50 \mathrm{mV}$. $\mathrm{s}^{-1}$ are nearly rectangular. However, the shape of the CVs are somewhat tilted at $80 \mathrm{mV} \cdot \mathrm{s}^{-1}$. The shape evolution of the CVs at different scan rates indicates that the ohmic resistance of the carbon electrodes is large at high scan rates. ${ }^{26}$

Galvanostatic charge-discharge is a commonly used method for studying electrochemical capacitors; much information, such as the capacitance and the long cycle capability of electrode materials, can be obtained from the experiments. ${ }^{27}$ The charge-discharge curves of the PSC-2 based electrodes and supercapacitors are shown in Fig.4. The coulombic efficiency of carbon electrodes is nearly $100 \%$, although the charge/discharge curves are not exactly linear. ${ }^{28}$ The specific capacitance can be calculated from the equation $C=I t_{d} \cdot(m \cdot \Delta V)^{-1}$, ${ }^{12,29}$ where $I$ is the current in the galvanostatic charge-discharge measurement, $m$ is the mass of the active materials, $t_{\mathrm{d}}$ is the variance metric of charge or discharge time, and $\Delta V$ is the potential window during the discharge process after $I R$ drop. As depicted in Fig.4A, the PSC-2 electrode had a capacitance of $378 \mathrm{~F} \cdot \mathrm{g}^{-1}$ at a current density of $0.1 \mathrm{~A} \cdot \mathrm{g}^{-1}$, and the capacitances decreased 

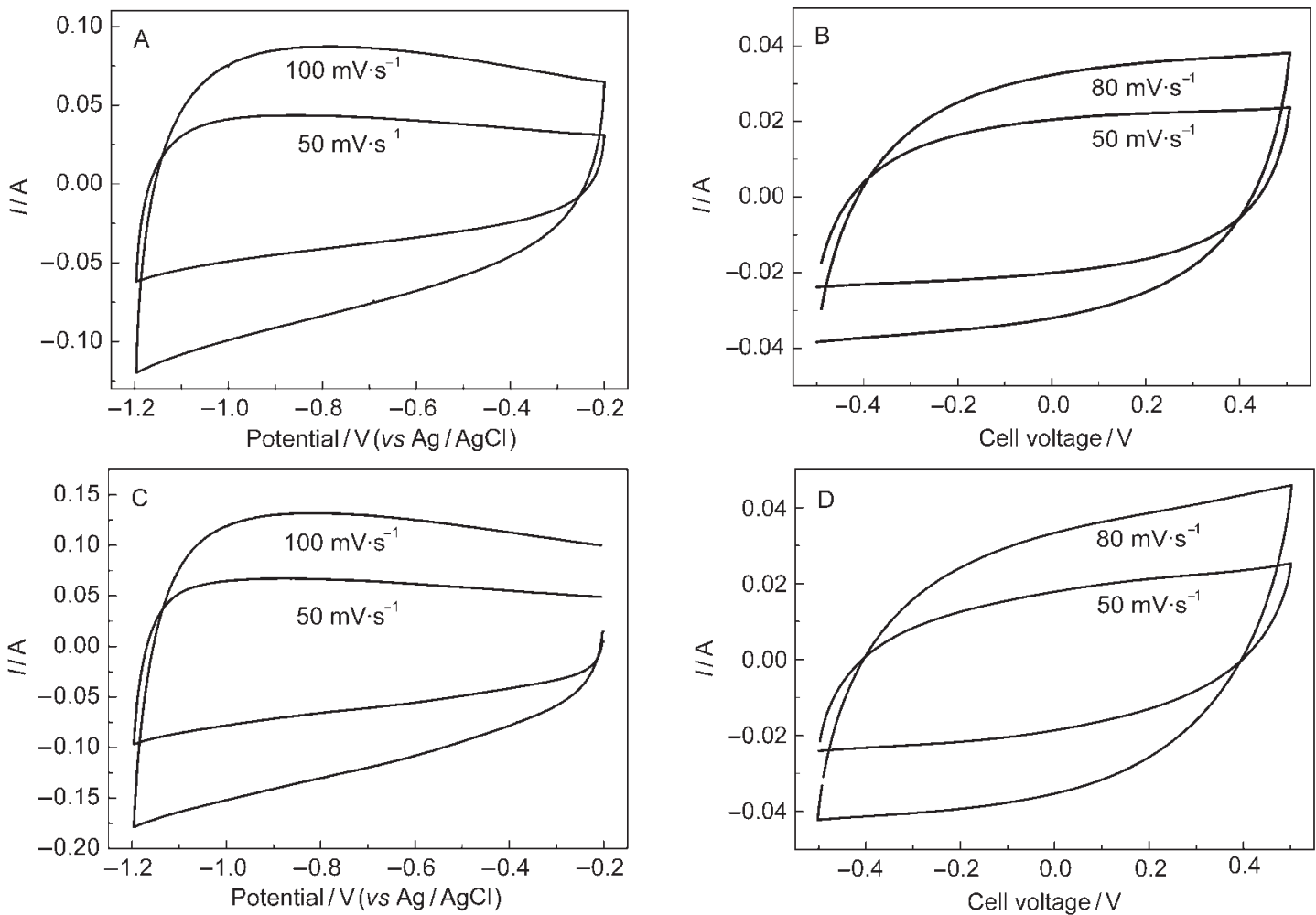

Fig.3 CV curves of PSC-1 (A, B) and PSC-2 (C, D) based electrodes (A, C) and supercapacitors (B, D)

to 322 and $310 \mathrm{~F} \cdot \mathrm{g}^{-1}$ at 0.5 and $1 \mathrm{~A} \cdot \mathrm{g}^{-1}$, respectively. However, the capacitance of the PSC-2 electrode dropped to $233 \mathrm{~F}$. $\mathrm{g}^{-1}$ at a current density of $0.1 \mathrm{~A} \cdot \mathrm{g}^{-1}$ and decreased to 208 and $205 \mathrm{~F} \cdot \mathrm{g}^{-1}$ at current densities of 0.5 and $1 \mathrm{~A} \cdot \mathrm{g}^{-1}$, respectively. For symmetrical supercapacitors, ${ }^{29,30}$ the capacitances were 130,109 , and $75 \mathrm{~F} \cdot \mathrm{g}^{-1}$ for PSC-2 at current densities of 0.2 , 0.5 , and $1 \mathrm{~A} \cdot \mathrm{g}^{-1}$ (Fig.4B), respectively, while the capacitance was $102 \mathrm{~F} \cdot \mathrm{g}^{-1}$ for PSC-1 at $0.2 \mathrm{~A} \cdot \mathrm{g}^{-1}$ and decreased to 74 and $52 \mathrm{~F} \cdot \mathrm{g}^{-1}$ at current densities of 0.5 and $1 \mathrm{~A} \cdot \mathrm{g}^{-1}$, respectively. These results indicate that the pore sizes of PSC-1 and PSC-2 are suitable for rapid diffusion of ions, similar to those of carbide-derived microporous carbons. ${ }^{1-3}$ The difference in the capacitances of PSC-1 and PSC-2 is mainly caused by variations in the specific surface areas.

The electrochemical stabilities of the active materials and their repeatability were also investigated by galvanostatic

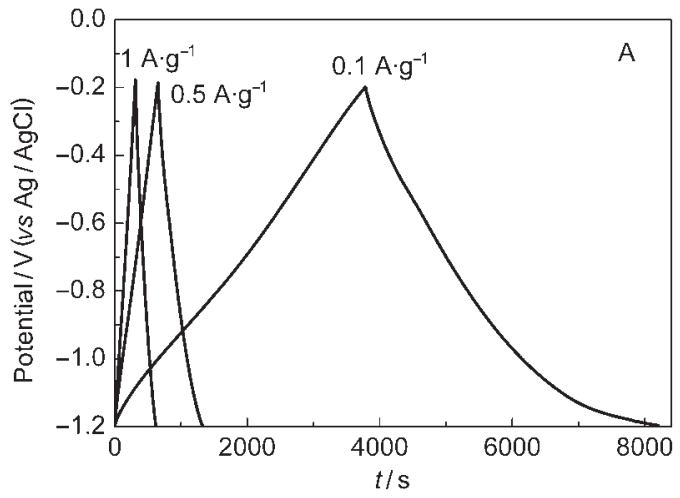

charge-discharge measurement. Fig. 5 shows the results of a cycling performance test on the PSC-2-based electrodes and supercapacitors. For the PSC-2 based symmetric supercapacitor, the capacitance retention was over $90.0 \%$ at a current density of $0.5 \mathrm{~A} \cdot \mathrm{g}^{-1}$ after 1000 cycles (Fig.5A). After 1000 cycles, the specific capacitance of the PSC-2 electrode at a current density of $2 \mathrm{~A} \cdot \mathrm{g}^{-1}$ was maintained more than $94.5 \%$ of the original value (Fig.5B). These results indicate that the peanut shell-based carbon electrodes and supercapacitors have good stability and capacitance retainability.

The excellent electrochemical performances of PSC-1 and PSC-2 can be attributed to their unique micropore structure and appropriate surface areas which afford a large enough electrode/electrolyte interface for charge accommodation. It should be noted that no products were obtained when solid mixtures of peanut shells and $\mathrm{NaOH}$ were undergone the same calcina-

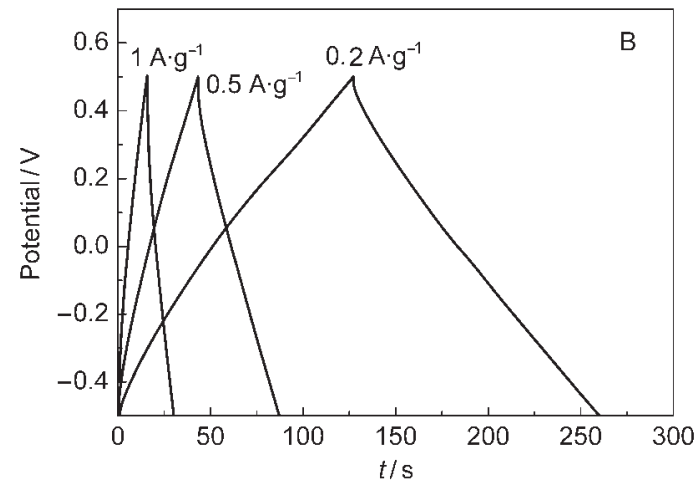

Fig.4 Galvanostatic charge-discharge curves of PSC-2-based electrodes (A) and supercapacitors (B) 


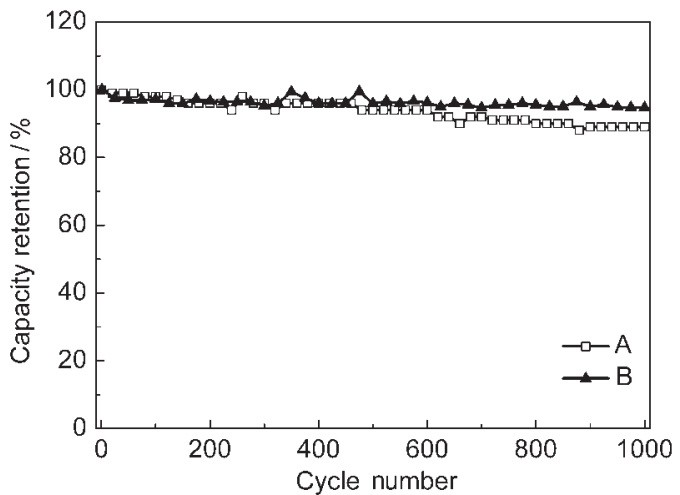

Fig.5 Cycling performance of the PSC-2-based supercapacitors (A) and electrodes (B)

tion procedure. The new procedure consisting of sample pretreatment with alkaline solutions increases the specific surface areas while the pore structure can be maintained. FTIR spectra showed that the peak at $1738 \mathrm{~cm}^{-1}$ in the PS-1 spectrum, ascribed to the $\mathrm{C}=\mathrm{O}$ stretching of the methyl ester and carboxylic acid groups in pectin, or the acetyl group in hemicelluloses, disappeared from the PS-2 spectrum. This indicates that pectin and hemicelluloses can be successfully extracted by a simple alkaline solution treatment. And thus microporous carbons with superior electrochemical properties from peanut shells are produced.

\section{Conclusions}

The alkaline solution activation method has been used to fabricate peanut-shell-based microporous carbons. It is found that PSC-2 derived via the activation method displays a higher surface area than that of PSC-1 produced by a non-activation method. The pore size distribution is unchanged. The CV curves of the samples in three-electrode systems and supercapacitors display rectangular shapes denoting the fast charge-discharge switching. The PSC-2 electrode shows a specific capacitance as high as $378 \mathrm{~F} \cdot \mathrm{g}^{-1}$ and good cycle stability. These results suggest that microporous carbon electrodes made from peanut shells have a potentially broad application as electrochemical capacitor electrode materials.

\section{References}

(1) Chmiola, J.; Yushin, G.; Gogotsi, Y.; Portet, C.; Simon, P.; Taberna, P. L. Science 2006, 313, 1760.

(2) Winter, M.; Brodd, R. J. Chem. Rev. 2004, 104, 4245.

(3) Conway, B. E. Electrochemical Supercapacitors: Scientific Fundamentals and Technological Applications; Kluwer Academic/Plenum Publisher: New York, 1999.

(4) Burke, A. J. Power Sources 2000, 91, 37.

(5) Kötz, R.; Carlen, M. Electrochim. Acta 2000, 45, 2483.

(6) Zhang, L. L.; Zhao, X. S. Chem. Soc. Rev. 2009, 38, 2520.
(7) Alvarez, S.; Blanco-Lopez, C.; Miranda-Ordieres, A. J.; Fuertes, A. B.; Centeno, T. A. Carbon 2005, 43, 866-870.

(8) Li, W.; Zhou, J.; Xing, W.; Zhuo, S. P.; Lü, Y. M. Acta Phys. -Chim. Sin. 2011, 27, 620. [李 文, 周 晋, 邢 伟, 祥淑萍, 吕忆民. 物理化学学报, 2011, 27, 620.]

(9) Wang, D. W.; Li, F.; Liu, M.; Lu, G. Q.; Cheng, H. M. Angew. Chem. Int. Edit. 2008, 47, 373.

(10) Raymundo-Piñero, E.; Leroux, F.; Béguin, F. Adv. Mater. 2006, $18,1877$.

(11) Ji, Q. Q.; Guo, P. Z.; Zhao, X. S. Acta Phys. - Chim. Sin. 2010, 26, 1254. [季倩倩, 郭培志, 赵修松. 物理化学学报, 2010, 26, 1254.]

(12) Zhang, C. X.; Long, D. H.; Xing, B. L.; Qiao, W. M.; Zhang, R.; Zhan, L.; Liang, X. Y.; Ling, L. C. Electrochem. Commun. 2008, 10, 1809.

(13) Vilaplana-Ortego, E.; Lillo-Ródenas, M. A.; Alcañiz-Monge, J.; Cazorla-Amorós, D.; Linares-Solano, A. Carbon 2009, 47, 2141.

(14) Wilson, K.; Yang, H.; Seo, C. W.; Marshall, W. E. Bioresour. Technol. 2006, 97, 2266.

(15) Watanabe, I.; Doi, T.; Yamaki, J.; Lin, Y. Y.; Fey, G. T. K. J. Power Sources 2008, 176, 347.

(16) Girgis, B. S.; Yunis, S. S.; Soliman, A. F. Mater. Lett. 2002, 57, 164.

(17) Li, Y. H.; Du, Q. J.; Wang, X. D.; Zhang, P.; Wang, D. C.; Wang, Z. H.; Xia, Y. Z. J. Hazard. Mater. 2010, 183, 583.

(18) Yang, J.; Qiu, K. Q. Chem. Eng. J. 2010, 165, 209.

(19) Garg, U. K.; Kaur, M. P.; Garg, V. K.; Sud, D. J. Hazard. Mater. 2007, 140, 60 .

(20) Singh, K. P.; Mohan, D.; Sinha, S.; Tondon, G. S.; Gosh, D. Ind. Eng. Chem. Res. 2003, 42, 1965.

(21) Karagoz, S.; Tay, T.; Ucar, S.; Erdem, M. Bioresour. Technol. 2008, 99, 6214.

(22) Wang, L. L.; Han, G. T.; Zhang, Y. M. Carbohyd. Polym. 2007, 69, 391.

(23) Janes, A.; Permann, L.; Arulepp, M.; Lust, E. Electrochem. Commun. 2004, 6, 313.

(24) Wang, D. W.; Li, F.; Zhao, J. P.; Ren, W. C.; Chen, Z. G.; Tan, J.; Wu, Z. S.; Gentle, I.; Lu, G. Q.; Cheng, H. M. ACS Nano 2009, 3, 1745.

(25) Peng, C.; Jin, J.; Chen, G. Z. Electrochim. Acta 2007, 53, 525

(26) Zheng, J. P. J. Electrochem. Soc. 2003, 150, A484.

(27) Eliad, L.; Salitra, G.; Soffer, A.; Aurbach, D. J. Phys. Chem. B 2002, 106, 10128.

(28) Yang, X. H.; Wang, Y. G.; Xiong, H. M.; Xia, Y. Y. Electrochim. Acta 2007, 53, 752.

(29) Stoller, M. D.; Ruoff, R. S. Energy Environ. Sci. 2010, 3, 1294.

(30) Khomenko, V.; Frackowiak, E.; Béguin, F. Electrochim. Acta 2005, 50, 2499 . 